\title{
Assessment of the Quality and Shelf-Life in Enriched $n 3$ PUFA Raw Beef Patties Using Dry Soybean Sprouts as Antioxidant
}

\author{
Mara Cristina Romero",2, Oscar Alfredo Garro',2, Ana María Romero1, \\ Ariel Germán Michaluk ${ }^{1,2}$, Mirtha Marina Doval' ${ }^{1}$, María Alicia Judis ${ }^{1}$ \\ ${ }^{1}$ Laboratorio de Industrias Alimentarias II, Universidad Nacional del Chaco Austral, Presidencia Roque Sáenz \\ Peña, Argentina \\ ${ }^{2}$ CONICET, Consejo Nacional de Investigaciones Científicas y Técnicas, Buenos Aires, Argentina \\ Email: mara@uncaus.edu.ar
}

Received 29 January 2014; revised 28 February 2014; accepted 7 March 2014

Copyright (C) 2014 by authors and Scientific Research Publishing Inc.

This work is licensed under the Creative Commons Attribution International License (CC BY).

http://creativecommons.org/licenses/by/4.0/

(c) (i) Open Access

\section{Abstract}

The appearance of fresh meat is a major determinant of its appeal to consumers. Ground beef in retail display oxidizes at a faster rate than whole muscle products; the use of antioxidants to break the radical chain reaction in the oxidation process is an effective method for slowing oxidation. Soybean is a complex matrix with several bioactive compounds, including peptides and proteins, isoflavones, saponins, and other compounds with antioxidant properties. This study was conducted for 1) to evaluate the antioxidant properties of dry soybeans sprouts (DSS) from Glycine $\max \left(\mathrm{L}\right.$.) Merr., MUNASQA ${ }^{\circledR} ; 2$ ) to evaluate quality characteristics of raw beef patties added with dried soybean sprouts at different levels $(0.5 \%, 1 \%$ and $2 \%)$ and soybean oil as a replacer of fat; and 3 ) to estimate color changes and lipid oxidation of $n 3$ fortified raw beef under frozen storage. Results showed that dry soybean sprouts had a high level of superoxide dismutase enzyme, high total phenolics and flavonoids content and appreciable vitamin c content. Although reduction power was low, 1,1-diphenyl-2-picrylhydrazyl (DPPH) and 2,2'-azino-bis(3-ethylbenzthiazoline-6sulphonic acid) (ABTS) radicals scavenging activity were elevated. When different concentrations of DSS were incorporated to enriched beef patties with soybean oil, the nutritional value was slightly affected, while that $n 3$ and $n 6$ fatty acid content were increased around three twice. The beef patties formulated with $1 \%$ of natural antioxidant showed significantly $(p<0.05)$ better color stability than those without antioxidants. The lipid oxidation was inhibited in all cases, and was strongly effective at $1 \%$ concentration of DSS being the reduced percent of thiobarbituric acid reactive substances (TBARS) comparable to butilated hydroxianisole (BHA). The results shown in this research suggest that dry soybeans sprouts could also be used as a cheap natural antioxidant source for meat products. 


\section{Keywords}

\section{Fresh Meat Products; Natural Antioxidant; Nutritional Composition; Color; Lipid Oxidation}

\section{Introduction}

The appearance of fresh retail meat is a major determinant of its appeal to consumers and, consequently, sales of the product. Ground beef retail display oxidizes at a faster rate than whole muscle products, and this oxidation causes a brown discoloration on the product which is discriminated by consumers [1]. Oxidation also results in the development of detrimental off-flavors and odors; thus, prevention of oxidation in ground beef has the potential to lengthen the shelf life and improve the profitability of ground beef products [2]. Complex mechanisms and reaction processes are involved in lipid oxidation, and it is generally accepted that oxidation occur mainly via a radical chain reaction including initiation, propagation, and termination stages [3] [4]. One effective method for slowing oxidation is to use antioxidants to break the radical chain reaction, thereby keeping the nutriational and sensory qualities of meat for longer.

Currently, polyunsaturated n3 fatty acids have been implicated as critical nutrients for human health, and fortification of foods with $n 3$ polyunsaturated fatty acids (PUFA) is an emerging area of commercial and academic interest. Therefore, different alternatives were studied to improve lipid profile in meat products, and to regain of the consumer trust in these products. Several investigators [5]-[7] have reported improved fatty acid profile in muscle foods by the addition of $n 3$ PUFA from vegetable oils such as soybean oil. However, incorporation of these fatty acids into food systems is potentially problematic due to their propensity to readily oxidize.

Compared with synthetic antioxidants, natural antioxidants are of great interest because of their safety and health characteristics. Most natural antioxidants are obtained from plant resources including culinary herbs, spices, fruits, vegetables, and oilseed products [4]. Soybean is a complex matrix with several bioactive compounds, including peptides and proteins, isoflavones, saponins, and other compounds with antioxidant properties [8]. The majority processed soybean products have been derived from dry mature soybeans. Although germination processes have been developed to overcome the disadvantages of soybean seed used in food products [9], it also was observed to increase their antioxidant properties. At present, germinated soybean products used for human consumption are the soybean sprouts which are commercialized as raw staple or minimally processed vegetables [10]. The development of functional foods from soybean sprouts as meat ingredients opens up new strategies to produce healthier foods.

Therefore, our objectives in this study were 1) to evaluate the antioxidant properties of dry soybeans sprouts from Glycine max (L.) Merr. (MUNASQA ${ }^{\circledR}$ ); and 2) to evaluate nutritional composition and fatty acid profile of meat patties with partial replacement of fat by soybean oil and the addition dried soybean sprouts and 3) to asses color changes and the effectiveness of this element in preventing or reducing lipid oxidation of fortified raw patties under frozen storage. Microbiological characteristics of the products were also evaluated.

\section{Materials and Methods}

\subsection{Dry Soybean Sprouts Preparation}

Dry soybean sprouts (DSS) were obtained from previously selected soybeans (Glycine max (L.) Merr., MUNASQA $^{\circledR}$, Tucumán, Argentina), selection was made based on shape and size. The beans were soaked in water for one hour at $25^{\circ} \mathrm{C}$ and then germinated in darkness at $30^{\circ} \mathrm{C}$ in a controlled temperature chamber. Once the sprouts reached $5 \mathrm{~cm}$ of length approximately they were separated from the beans, washed in sterile water and dehydrated at $40^{\circ} \mathrm{C}$ in a static drying chamber until $89 \%$ dry weight. Then dry soybean sprouts were ground to a powder.

\subsection{Preparation of Hydrophilic and Hydro Alcoholic Extracts}

Two grams of dry soybean sprouts were ground in a pepper grinder and extracted overnight at $4^{\circ} \mathrm{C}$ with $40 \mathrm{~mL}$ of $50 \mathrm{mmol}$ tris-HCl buffer (pH 8.0) containing $1 \mathrm{mmol}$ ethylenediaminetetraacetic acid (EDTA, Merck-KGaA, Darmstadt, Germany) to obtain a higher enzymatic concentration. The resulting hydrophilic crude extract was 
centrifuged in a refrigerated centrifuge (Rolco* CM 2036, Aparatos para Médicos Laboratorios e Industrias, Buenos Aires, Argentina) at $1000 \times \mathrm{g}$ for $20 \mathrm{~min}$. The upper layer obtained after centrifugation was used for superoxide dismutase assay.

At the same time, $2 \mathrm{~g}$ of dried and ground soybean sprouts were extracted twice with a mixture of ethanol:water (70:30). The mixture was centrifuged for 20 minutes and the supernatant was dried under vacuum $\left(50^{\circ} \mathrm{C}\right.$ and $\left.4000 \mathrm{~Pa}\right)$ to obtain a dry extract, which was used for total phenols, flavonoids and reducing power determinations, DPPH and ABTS assays, and measurement of metal chelating activity.

Notions of the experiment: DPPH:1,1-diphenyl-2-picrylhydrazyl and ABTS: 2,2'-azino-bis(3-ethylbenzthiazoline-6-sulphonic acid).

\subsection{Antioxidant Properties}

\subsubsection{Superoxide Dismutase Assay (SOD)}

This SOD assay is routinely used for the measurement of superoxide dismutase in barley. The method is based on the inhibition of the reduction of cytochrome c by superoxide dismutase enzyme when the superoxide radical anions are generated by a xanthine/xanthine oxidase system [11]. SOD E.C. 1.15.1.1 from Bacillus stearothermophilus was used as a standard (Sigma-Aldrich, St Louis, MO, United States)

One centimeter light path glass cuvettes were used containing $150 \mu \mathrm{mol}$ of potassium phosphate, $\mathrm{pH}$ 7.8; 0.3 $\mu$ mol EDTA; $0.03 \mu \mathrm{mol}$ ferricytochrome $c$; $0.15 \mu \mathrm{mol}$ xanthine; $10 \mu \mathrm{L}$ xanthine oxidase $\left(0.65 \mathrm{units}^{\mathrm{mg}} \mathrm{m}^{-1} \mathrm{pro}^{-}\right.$ teins) ; $10 \mu \mathrm{L}$ hydrophilic crude extract without dilution and water to a total volume $3 \mathrm{ml}$. The mixtures were incubated at $25^{\circ} \mathrm{C}$ for 2 min without xanthine, which was then added to start the reaction. The reduction of cytochrome $c$ was followed by recording the increase in absorbance at $550 \mathrm{~nm}$ over a period of $3 \mathrm{~min}$, using a Beckman DU ${ }^{\circledR}$ 640B spectrophotometer (Fullerton, CA, United States). One unit of superoxide dismutase is defined as the amount that lessens the rate of reduction of cytochrome $c$ by $50 \%$.

\subsubsection{Total Phenolic Compounds Determination}

Total phenolics content was determined using Folin-Ciocalteau [12]. One milliliter of diluted dry extract or a standard solution $(1 \mathrm{ml})$ was added to $10 \mathrm{ml}$ deionised water and $2 \mathrm{ml}$ Folin-Ciocalteau reagent (Merck, Darmstadt, Germany). The mixture was then allowed to stand for 5 minutes and $2 \mathrm{ml}$ of sodium carbonate were added (saturated solution). After 1 hour in darkness, the absorbance at $735 \mathrm{~nm}$ was measured. The concentration of total phenolics was expressed as mg of gallic acid equivalent per $\mathrm{g}$ of dry extract by using an equation that was obtained from a standard gallic acid graph $\left(\mathrm{R}^{2} 0.995\right)$.

\subsubsection{Flavonoids Determination}

Total flavonoids were measured by a colorimetric assay according to Kim et al. [13] with some modification. To $4 \mathrm{ml} \mathrm{H}_{2} \mathrm{O}$ in a $10 \mathrm{ml}$ volumetric flask was added $1 \mathrm{ml}$ of sample:water (50:50, v/v) or standard solutions of quercetin (0 - $500 \mathrm{mg} \cdot \mathrm{L}^{-1}$, Sigma-Aldrich, St Louis, MO, United States). At zero time, $0.3 \mathrm{ml}$ of $50 \mathrm{~g} \cdot \mathrm{L}^{-1} \mathrm{NaNO}_{2}$ was added to the flask. After $5 \mathrm{~min}, 0.3 \mathrm{ml} \mathrm{AlCl} 3\left(100 \mathrm{~g} \cdot \mathrm{L}^{-1}\right)$ was added. At $6 \mathrm{~min}, 2 \mathrm{ml}$ of $1 \mathrm{~mol} \cdot \mathrm{L}^{-1} \mathrm{NaOH}$ were added to the mixture and immediately diluted with $2.4 \mathrm{ml}$ of $\mathrm{H}_{2} \mathrm{O}$. Absorbance of the mixture was read at $510 \mathrm{~nm}$ versus water blank. Total flavonoids were expressed as mg quercetin equivalents $\mathrm{g}^{-1}$ of dry matter.

\subsubsection{Determination of Vitamin C Content}

The content of vitamin $\mathrm{C}$ was determined by the titration procedure. Aliquots of $0.1 \mathrm{ml}$ of the extract were diluted in $20 \mathrm{ml}$ of oxalic acid $\left(2 \mathrm{~g} \cdot \mathrm{L}^{-1}\right)$ for titration with $0.4 \mathrm{~g} \cdot \mathrm{L}^{-1}$ dichlorophenol-indophenol (Anedra, San Fernando, Argentina). The ascorbic acid concentration was calculated by comparison with $\mathrm{L}(+)$-ascorbic acid standard (Merck-KGaA, Darmstadt, Germany).

\subsubsection{Reducing Power Determination}

The reducing power was determinate as described by Oyaizu [14]. Various dilutions of the previously obtained extract (0.01:0.99; 0.02:0.98; 0.05:0.95; 0.1:0.90; v/v) were mixed with $2.5 \mathrm{ml}$ of $200 \mathrm{mM}$ sodium phosphate buffer (pH 6.6) and $2.5 \mathrm{ml}$ of $10 \mathrm{~g} \cdot \mathrm{L}^{-1}$ potassium ferricyanide (Sigma-Aldrich, St Louis, MO, United States). The reaction mixture was incubated in a temperature-controlled water bath at $50^{\circ} \mathrm{C}$ for 20 minutes, followed by the addition of $1 \mathrm{ml}$ of $10 \%$ trichloroacetic acid. The mixture then was centrifuged and the supernatant obtained 
$(1 \mathrm{ml})$ was treated with $1 \mathrm{ml}$ distilled water and $200 \mu \mathrm{l}$ of $0.1 \% \mathrm{FeCl}_{3}$. The absorbance of the reaction mixture was measured at $700 \mathrm{~nm}$ in a spectrophotometer. Higher absorbance indicates a higher reducing power.

\subsubsection{Scavenging Activity on DPPH and ABTS Radicals}

The radical scavenging ability of crude extract was determined at different concentrations in an ethanolic DPPH

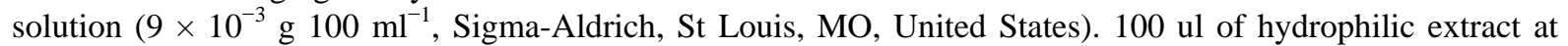
various dilutions with water $(0.01: 0.99 ; 0.02: 0.98 ; 0.05: 0.95 ; 0.1: 0.90, \mathrm{v} / \mathrm{v})$ were added to three milliliters of ethanolic solution of DPPH. The decrease of absorbance at $517 \mathrm{~nm}$ was continuously recorded in a UV-Vis spectrophotometer for 10 minutes at room temperature.

The radical scavenging activity of the ABTS radical cation was measured as the informed by Re et al. [15]. The bleaching rate of ABTS in the presence of the sample was spectrophotometrically monitored at $734 \mathrm{~nm}$ during 10 minutes and the reaction was started by adding $100 \mu \mathrm{l}$ of antioxidant solutions.

The inhibition percentage of free radicals DPPH and ABTS (I \%) was calculated using the following equation [16]:

$$
\mathrm{I} \%=\frac{\left(\mathrm{A}_{\text {blank }}-\mathrm{A}_{\text {sample }}\right)}{\mathrm{A}_{\text {blank }}} \times 100 \%
$$

Furthermore, radical scavenging activities for both determinations were expressed as mg of Vitamin C equivalent per g of sample through the dose-response curves for Vitamin C.

\subsubsection{Measurement of Metal Chelating Activity}

The 2,2'-bipyridyl competition assay was conducted to measure the $\mathrm{Fe}^{2+}$ chelating activity of the samples as the indicated by Zhou et al. [17]. The reaction mixture contained $0.1 \mathrm{~mL}$ of $1 \mathrm{mM} \mathrm{FeSO}_{4}$ solution, $50 \mathrm{uL}$ of sample, $0.3 \mathrm{ml}$ of $10 \%$ hydroxylamine- $\mathrm{HCl}, 0.4 \mathrm{ml}$ of 2,2'-bipyridyl solution $(0.1 \%$ in $0.2 \mathrm{M} \mathrm{HCl})$, and $0.8 \mathrm{ml}$ of Tris$\mathrm{HCl}$ buffer ( $\mathrm{pH}$ 7.4). The absorbance at $522 \mathrm{~nm}$ was measured and used to determine $\mathrm{Fe}^{2+}$ chelating activity using EDTA as the reference standard and was expressed in mg EDTA equivalents per gram of dry extract.

\subsection{Patties Preparation}

Enriched beef patties were prepared using fresh lean beef meat and pork backfat obtained from local markets, and soy oil containing SFA 16 g/100g, MUFA 35 g/100g, PUFA $n 660$ g/100g and $n 36$ g/100g (Aceitera General Deheza S.A., Córdoba, Argentina) that was used as fat partial replacer.

Five different formulations were elaborated as follows: one control sample without addition of antioxidants (C) with beef and $20 \%$ of pork back fat (similar to commercial products); and four enriched beef patties (EP) with beef, $10 \%$ of pork back fat, $10 \%$ of soybean oil and with addition of DSS as natural antioxidant $(0.5 \%, 1 \%$ and $2 \%$ ), and $0.01 \%$ of butylated hydroxyanisole (BHA) as antioxidative positive control.

All formulations were shaped using Petri-dish $(90 \mathrm{~mm} \times 20 \mathrm{~mm})$ to obtain 60 patties of approximately $100 \mathrm{~g}$ each one. The samples were packaged in oxygen permeable bags $\left(2000 \mathrm{~cm}^{3} / \mathrm{m}^{2}\right.$ day) using a packing machine (RAPI-VAC S-750 ${ }^{\circledR}$ SERVIVAC S.R.L., Buenos Aires, Argentina) stored at $-18^{\circ} \mathrm{C}$ and analyzed at 0, 30, 60 and 90 days.

Notions of the experimental samples: DSS: dry soybean sprout; C: control patty; EP: enriched patties; EP $0.5 \%$ : enriched patty with $0.5 \%$ of DSS; EP $1 \%$ : enriched patty with $1 \%$ of DSS; EP $2 \%$ : enriched patty with $2 \%$ of DSS; EP 0.01\% BHA: enriched patty with $0.01 \%$ of BHA.

\subsubsection{Proximate Composition}

Moisture, protein, fat and ash contents were analyzed according to AOAC methods [18]. Total carbohydrates were quantified using Clegg anthrone methods [19] on an UV-Vis Beckman DU 640B ${ }^{\circledR}$ spectrophotometer (Fullerton, CA, United States).

\subsubsection{Fatty Acids Composition}

Total lipids were extracted as described by Bligh and Dyer [20] and fatty acid methyl esters were obtained according to AOAC methods [18] and analyzed using GC Mass Spectrometer (Thermo Fisher Scientific ${ }^{\circledR}$, Austin, TX, USA) equipped with a 100\% Cyanopropyl silicone capillary column (SPTM-2340 100 m, 0.32 mm ID, 
film thickness $0.25 \mathrm{~mm}$ ). The oven temperature was held at $140^{\circ} \mathrm{C}$ for $5 \mathrm{~min}$ and subsequently increased at $4^{\circ} \mathrm{C} / \mathrm{min}$ to $220^{\circ} \mathrm{C}$. Injector temperature was $250^{\circ} \mathrm{C}$. Identification of fatty acid methyl esters was based on retention time of standard esters (Supelco ${ }^{\circledR} 37$ Components FAME Mixture, Bellefonte, PA) eluting from the capillary column. Peak areas were integrated using chromatography data software, and concentrations of each ester were calculated as a percentage of the total area of the chromatogram.

\subsubsection{Color Determination}

Color measurements ( $\mathrm{L}^{*}$, $\mathrm{a}^{*}$ and $\mathrm{b}^{*}$ values) were performed using an Evolution $600 \mathrm{UV}-\mathrm{Vis}$ (Thermo Scienti$\mathrm{fic}^{\circledR}$, Austin, TX, USA) equipped with a integrate sphere using a VISIONlite colorCalc software to obtain CIE $L^{*}, a^{*}, b^{*}$ values. The $L^{*}$ value represents lightness and $a^{*}$ and $b^{*}$ values represent redness and yellowness, respectively. Color measurements of fresh patties were recorded on days 1 and 90 of storage.

\subsubsection{Measurement of Lipid Oxidation}

Lipid oxidation of beef patties was monitored by measuring the formation conjugated dienes (CD), peroxide value (PV) and thiobarbituric acid reactive substances (TBARS).

Conjugated dienes were determined as Aubourg [21], pre-weighed lipid samples were diluted with hexane and the absorbance was measured at $233 \mathrm{~nm}$ in a Beckman $\mathrm{DU}^{\circledR}$ 640B spectrophotometer. The hydroperoxides conjugated dienes concentration was expressed in milliliter per milligram of lipids. The results were calculated as:

$$
\mathrm{CD}=\frac{\mathrm{B} \times \mathrm{V}}{\mathrm{W}}
$$

Where Bis the absorbance reading, $\mathrm{V}$ denotes the volume (ml) of the solvent and $\mathrm{w}$ is the mass (mg) of sample measured.

Determination of PV was conducted by the IDF method [22]. $0.01 \mathrm{~g}$ of samples were dissolved in $9.9 \mathrm{ml}$ chloroform:methanol (70:30) solution and $0.05 \mathrm{ml}$ of 30\% (w/v) ammonium thiocyanate were added and mixed. Precisely $5 \mathrm{~min}$ after the addition of $0.05 \mathrm{ml}$ of ferrous chloride in $3.5 \% \mathrm{v} / \mathrm{v}$ hydrochloride acid to the reaction mixture, the absorbance of the resulting red color was measured at $501 \mathrm{~nm}$ against solvent solution as blank. Results were expressed in meq $\mathrm{O}_{2} / \mathrm{kg}$ of lipids.

A modified thiobarbituric acid reactive substances (TBARS) method was used to evaluate the extent of lipid oxidation according to Ahn and Kim [23]. One hundred milligrams of lipids were taken, and the following reactives were sequentially added: $100 \mu \mathrm{l}$ (BHA $36 \mathrm{~g} / \mathrm{l}$ ) and $2 \mathrm{ml}$ of TBA/trichloroacetic acid (TCA) solution (20 $\mathrm{mM}$ TBA in $150 \mathrm{~g} / \mathrm{l} \mathrm{TCA}$ ). The mixture was heated in a $90^{\circ} \mathrm{C}$ water bath for $15 \mathrm{~min}$ and cooled at room temperature. Afterwards, two milliliters of chloroform were added and the mixture was centrifuged at $1.000 \mathrm{rpm}$ for 15 min. The absorbance of the supernatant was measured at $532 \mathrm{~nm}$ in an UV-Vis Beckman DU 640B ${ }^{\circledR}$ spectrophotometer against a blank containing $0.1 \mathrm{ml} \mathrm{H}_{2} \mathrm{O}$ and $2 \mathrm{ml}$ TBA/TCA solution. Malonaldehyde (MAD) standard curves were prepared by 1,1,3,3-tetramethoxypropane and TBARS were expressed as $\mathrm{mg} / \mathrm{kg}$ of MAD equivalents of samples.

\subsubsection{Antioxidant Activity}

The antioxidative activity at the end of assay was expressed for each indicator as inhibition or reduction percent of peroxidation $(R P \%)$ with a control containing no antioxidant.

$$
=\frac{(\text { peroxidation indicator value without antioxidant })-(\text { peroxidation indicator value with antioxidant })}{\text { peroxidation indicator value without antioxidant }} \times 100
$$

A higher percentage indicates a higher antioxidant activity.

\subsection{Microbiological Analyses}

Ten gram of each sample were homogenized with $90 \mathrm{ml}$ of $0.1 \%$ peptone water and appropriate serial dilutions were plated in duplicate on plate count agar (PCA) at $37^{\circ} \mathrm{C}$ for $48 \mathrm{~h}$. Results were expressed as log number of colony forming units per $\mathrm{g}$ of sample (log cfu/g). 


\subsection{Statistical Analyses}

The results were expressed as mean \pm standard deviation. All statistical tests were performed using Statgraphics Plus for Windows software package. Data obtained from proximate composition, fatty acid profile, color measurement and oxidative stability parameters for each storage time $(0,15,30,60$ and 90 days) were analyzed with one-way analysis of variance (ANOVA) using the formulations as factor. Differences were considered significant at $\mathrm{p}<0.05$ and the Fisher's Multiple Range Tests were used for comparison of mean values.

All experiments and analyses were carried out in triplicate.

\section{Results and Discussion}

\subsection{Antioxidant Properties of Dry Soybean Sprouts}

Multifarious antioxidant systems are very important for protecting cellular membranes and organelles from the damaging effects of active oxygen species. These include antioxidant enzymes, no enzymatic antioxidants and secondary metabolites [24]. Also, the antioxidant reactivity characterizes the starting dynamics of antioxidation at certain concentration of an antioxidant or antioxidant mixture [25]. Table 1 shows a summary of the antioxidant properties of DSS.

SOD activity in crude extract from dry soybeans sprouts was higher than soya bean $\left(640 \mathrm{U} \cdot \mathrm{g}^{-1}\right)$, wheat flour (56 $\left.\mathrm{U} \cdot \mathrm{g}^{-1}\right)$ and commercial ale malts $\left(170 \mathrm{U} \cdot \mathrm{g}^{-1}\right)$ according to reported by Bamforth [11]. This value also is higher than the superoxide dismutase from garlic $\left(20.6 \mathrm{U} \cdot \mathrm{g}^{-1}\right)$ [26], and those in selected Indian medicinal plants [24]. However this value is lower than the values informed in dry soybeans sprouts from NIDERA ${ }^{\circledR}$ Glycine $\max (\mathrm{L})$ Merr. (3110 U/g) [27].

The antioxidant properties measured as phenolics compounds content, flavonoids content, vitamin C content and valued as DPPH and ABTS radicals scavenging activity and reducing power, would allow estimating the antioxidant capacity of vegetable natural extracts. The phenolics content of hydroalcoholic extract from soya sprouts and flavonoids content were higher than those reported in aqueous extracts from rosemary, roasted Arabica coffee and grape skin which ranged between 67 and $198 \mathrm{mg}$ phenol equivalents/g [28], and that the informed in 10 edible plants whose values were from 3.13 to $72.30 \mathrm{mg}$ gallic acid/g [29]. The vitamin C content of dry soya sprouts was high in contrast with other investigations [27] [30] which reported that dry soya bean seed did not contain vitamin C, but after 3 days of germination the vitamin C level reached $250 \mathrm{mg} \cdot \mathrm{Kg}^{-1}$ dry matter, therefore the value found for this variety of soybeans is higher than the informed by this author.

Relating to reducing power, similar results was reported before [27] indicating that soya bean without fermentation did not contain reductones, chemical substances responsible of reducing power.

Free radical-scavenging is one of the known mechanisms by which antioxidants inhibit the lipid oxidation [31]. The DPPH assay is one of the most widely employed and preferred methods for measuring the radical scavenging activity of plant extracts. This assay is rapid, relatively simple, and easily standardized [32]. At the same time the ABTS radical assay determines the single electron-transfer capabilities of these [15]. In the present study the DPPH and ABTS radicals scavenging capacity of the dry soybean sprout extracts was elevated, probably due to the high phenolic and flavonoids content in this ingredient.

Table 1. Antioxidant properties of dry soybean sprout extracts.

\begin{tabular}{cc}
\hline & Results \\
\hline SOD & $1385 \pm 39 \mathrm{U} / \mathrm{g}$ dry matter \\
Phenolics content & $562.11 \mathrm{mg} \pm 15 \mathrm{mg}$ acid gallic equivalents/g dry matter \\
Flavonoids content & $7.41 \pm 4 \mathrm{mg}$ quercetin equivalents/g of dry matters \\
Vitamin C content & $475.54 \pm 30 \mathrm{mg} / \mathrm{Kg}$ dry matter \\
Reducing power & $16.54 \pm 3.7 \mathrm{mg}$ vitamin C equivalents/g dry matter \\
DPPH & $121.88 \pm 9.1 \mathrm{mg}$ vitamin C equivalents/g dry matter \\
ABTS & $11.99 \pm 4.8 \mathrm{mg}$ vitamin C equivalents/g dry matter \\
Metal chelating activity & $43.2 \pm 2.1 \mathrm{mg} / \mathrm{g}$ dry matter \\
\hline
\end{tabular}

Antioxidants compounds and antioxidant activity of DSS extracts. 
Also was determinate that DSS extract presents $43.2 \pm 2.1 \mathrm{mg}$ EDTA equivalents/g of metal chelating activity. Transition metals are known to act as catalysts of the oxidation of lipids; therefore DSS would have great effect in retarding lipid peroxidation and subsequently prevention rancidity of foods due to the chelating ability of $\mathrm{Fe}^{2+}$.

\subsection{Nutritional Value and Lipidic Profile of Enriched Beef Patties}

Proximate composition of DSS and enriched burgers with soybean oil as fat partial replacer and different concentrations of the additive are shown in Table 2.

Since dehydrated soybean products are not commercialized as additives or similar products, due to the degree of processing they have, the comparison of the nutritional properties can be done with other products from soy as flour and isolated protein. The protein, carbohydrate and ashes contents of DSS are in concordance with the values found for different soybean flours samples, while the values found for moisture and fat are lower than the informed by Ndife et al. [33] and Eze et al. [34]. These results shows the potentials use of dry soybean sprouts, which is rich in protein of high biological value and have not been adequately exploited in manufacture of different types of food products.

Moisture analysis of patties showed significant differences $(\mathrm{p}<0.05)$ between formulations, the addition of DSS decreased moisture content in all samples. This is in agreement with other researchers [35]-[37] who reported a decrease in moisture content of beef patties formulated with oat flour, bambara groundnut and Wakame, probably because of increased solid contents.

The higher concentration of DSS, the higher carbohydrate content of raw patties ( $p<0.05)$, which could be due to the high content of carbohydrates in soybean sprouts.

The differences in protein content and fat content between formulations were found to be significant $(\mathrm{p}<$ 0.05). The effect of DSS concentration however was found to be non-significant; although the protein and fat contents at zero DSS concentration were higher than the enriched DSS patties. Fat content of the raw patties decreased when the levels of DSS were increased, which is in concordance with other reports [36].

Ashes analysis of all samples did not show significant differences between formulations $(\mathrm{p}<0.05)$.

Five fatty acids composed by palmitic $(21.50 \pm 0.14)$, oleic $(9.65 \pm 0.05)$, linoleic (37.60 \pm 0.15$)$, linolenic (12.47 \pm 0.004$)$ and docosaenoic (4.14 \pm 0.16$)$ comprised around $85 \%$ of total fatty acids in DSS analyzed samples. The fatty acid compositions of raw patties manufactured with soybean oil as replacer of pork back-fat are shown in Table 3.

Six fatty acids, namely palmitic, stearic, oleic, linoleic, linolenic and CLA (10c, 12c) acids, comprised around $97 \%$ of total fatty acids in analyzed meat products. As expected, the treatment with vegetable oil had a significant effect on the fatty acid composition of these products. The addition of the vegetable oils to burger patties significantly reduced the content of palmitic and stearic fatty acids, and therefore, SFA were decreased compared to the control counterparts. Also $n 3$ PUFA of short chain content increased from $1.65 \%$ to $4.50 \%$, and $n 6$ PUFA from $21.32 \%$ to $40.87 \%$. The PUFA/SFA relationship increased around three times, and the $n 6 / n 3$ ratio was maintained below 10 .

The fatty acid composition of meat foods has a great impact on the nutritional value, oxidative stability and sensory properties [38]. Products obtained in this way (including $10 \%$ of soybean oil in the recipe of porcine

Table 2. Mean values of proximate composition of dry soybean sprouts and enriched raw patties (EP) formulated with different concentrations of DSS.

\begin{tabular}{|c|c|c|c|c|c|}
\hline Samples & Moisture & Protein & Carbohydrate & Ashes & Total Fat \\
\hline DSS & $10.16 \pm 0.001$ & $43.51 \pm 1.12$ & $39.52 \pm 0.74$ & $6.62 \pm 0.006$ & $0.97 \pm 0.04$ \\
\hline $\mathrm{C}$ & $62.09 \pm 0.11^{\mathrm{b}}$ & $22.65 \pm 0.57^{\mathrm{b}}$ & $0.58 \pm 7.50 \mathrm{E}-05^{\mathrm{b}}$ & $3.59 \pm 0.46^{\mathrm{a}}$ & $19.49 \pm 0.01^{\mathrm{c}}$ \\
\hline EP $0.01 \%$ BHA & $60.59 \pm 0.001^{\mathrm{ab}}$ & $18.95 \pm 1.02^{\mathrm{a}}$ & $0.44 \pm 4.24 \mathrm{E}-06^{\mathrm{a}}$ & $3.41 \pm 0.12^{\mathrm{a}}$ & $18.25 \pm 0.004^{\mathrm{b}}$ \\
\hline EP $0.5 \%$ DSS & $59.50 \pm 0.62^{\mathrm{a}}$ & $19.36 \pm 0.07^{\mathrm{a}}$ & $0.66 \pm 5.43 \mathrm{E}-06^{\mathrm{c}}$ & $3.14 \pm 0.004^{\mathrm{a}}$ & $18.49 \pm 0.03^{b}$ \\
\hline EP 1\% DSS & $59.05 \pm 0.27^{\mathrm{a}}$ & $19.15 \pm 0.86^{\mathrm{a}}$ & $0.77 \pm 8.13 \mathrm{E}-05^{\mathrm{d}}$ & $3.36 \pm 0.20^{\mathrm{a}}$ & $18.35 \pm 0.001^{b}$ \\
\hline EP 2\% DSS & $59.83 \pm 0.03^{\mathrm{a}}$ & $19.36 \pm 0.20^{\mathrm{a}}$ & $0.89 \pm 0.001^{\mathrm{e}}$ & $3.02 \pm 0.001^{\mathrm{a}}$ & $17.30 \pm 0.06^{\mathrm{a}}$ \\
\hline
\end{tabular}

Results are presented as means \pm standard deviation of three replicates. Different letters $\left({ }^{\mathrm{a}}\right)$ in the same column denote significant differences among formulations ( $<$ 0.05). DSS: dry soybean sprout; C: control patty; EP: enriched patties; EP 0.5\%: enriched patty with 0.5\% of DSS; EP 1\%: enriched patty with 1\% of DSS; EP 2\%: enriched patty with 2\% of DSS; EP 0.01\% BHA: enriched patty with $0.01 \%$ of BHA. 
Table 3. Fatty acid profile of enriched patties formulated with different concentrations of DSS in g/100g dry product.

\begin{tabular}{|c|c|c|c|c|c|}
\hline Fatty acids & $\mathrm{C}$ & ЕР ВНА $0.01 \%$ & EP DSS $0.5 \%$ & EP DSS 1\% & EP DSS $2 \%$ \\
\hline$(14: 0)$ & $1.23 \pm 0.006^{c}$ & $0.60 \pm 0.02^{\mathrm{a}}$ & $0.61 \pm 0.007^{\mathrm{a}}$ & $0.73 \pm 0.006^{b}$ & $0.69 \pm 0.05^{\mathrm{b}}$ \\
\hline$(16: 0)$ & $21.49 \pm 0.11^{\mathrm{d}}$ & $15.19 \pm 0.23^{\mathrm{a}}$ & $15.13 \pm 0.11^{\mathrm{a}}$ & $15.98 \pm 0.26^{c}$ & $15.54 \pm 0.16^{\mathrm{b}}$ \\
\hline$(16: 1)$ & $1.90 \pm 0.005^{c}$ & $0.93 \pm 0.03^{\mathrm{a}}$ & $0.94 \pm 0.01^{\mathrm{a}}$ & $1.07 \pm 0.07^{\mathrm{b}}$ & $0.98 \pm 0.02^{\mathrm{a}}$ \\
\hline$(17: 0)$ & $0.53 \pm 0.004^{c}$ & $0.29 \pm 0.01^{\mathrm{a}}$ & $0.29 \pm 0.004^{\mathrm{a}}$ & $0.34 \pm 0.003^{b}$ & $0.32 \pm 0.02^{\mathrm{b}}$ \\
\hline$(17: 1)$ & $0.48 \pm 0.00^{\mathrm{c}}$ & $0.23 \pm 0.001^{\mathrm{b}}$ & $0.12 \pm 0.16^{\mathrm{a}}$ & $0.26 \pm 0.03^{\mathrm{b}}$ & $0.23 \pm 0.003^{\mathrm{b}}$ \\
\hline$(18: 0)$ & $11.77 \pm 0.06^{c}$ & $7.69 \pm 0.21^{\mathrm{a}}$ & $7.86 \pm 0.05^{\mathrm{a}}$ & $8.30 \pm 0.05^{\mathrm{b}}$ & $8.16 \pm 0.22^{\mathrm{b}}$ \\
\hline$(18: 1) \mathrm{t}$ & $0.41 \pm 0.08^{\mathrm{b}}$ & $0.17 \pm 0.15^{\mathrm{a}}$ & $0.05 \pm 0.00^{\mathrm{a}}$ & $0.21 \pm 0.05^{\mathrm{ab}}$ & $0.26 \pm 0.08^{\mathrm{ab}}$ \\
\hline$(18: 1) \mathrm{c}$ & $39.23 \pm 0.14^{c}$ & $29.25 \pm 0.37^{\mathrm{a}}$ & $29.33 \pm 0.44^{\mathrm{a}}$ & $30.56 \pm 0.99^{\mathrm{b}}$ & $29.56 \pm 0.11^{\mathrm{a}}$ \\
\hline$(18: 2) n 6$ & $12.42 \pm 0.03^{\mathrm{a}}$ & $37.57 \pm 0.64^{c}$ & $36.77 \pm 0.03^{\mathrm{bc}}$ & $34.61 \pm 1.90^{\mathrm{b}}$ & $35.93 \pm 0.03^{b c}$ \\
\hline$(20: 0)$ & $-^{\mathrm{a}}$ & $0.27 \pm 0.01^{\mathrm{b}}$ & $0.26 \pm 0.002^{\mathrm{b}}$ & $0.25 \pm 0.04^{\mathrm{b}}$ & $0.29 \pm 0.02^{\mathrm{b}}$ \\
\hline$(18: 3) n 3$ & $1.65 \pm 0.03^{\mathrm{a}}$ & $4.63 \pm 0.07^{\mathrm{c}}$ & $4.50 \pm 0.03^{\mathrm{bc}}$ & $4.38 \pm 0.23^{b}$ & $4.47 \pm 0.03^{\mathrm{bc}}$ \\
\hline CLA, $n 6$ & $8.89 \pm 0.02^{\mathrm{c}}$ & $3.03 \pm 0.06^{\mathrm{a}}$ & $4.11 \pm 0.85^{\mathrm{b}}$ & $3.93 \pm 0.54^{\mathrm{b}}$ & $3.24 \pm 0.14^{\mathrm{ab}}$ \\
\hline SFA & $35.01 \pm 0.18^{\mathrm{c}}$ & $24.04 \pm 0.46^{\mathrm{a}}$ & $24.16 \pm 0.14^{a}$ & $25.60 \pm 0.22^{\mathrm{b}}$ & $25.00 \pm 0.47^{\mathrm{b}}$ \\
\hline MUFA & $42.02 \pm 0.22^{\mathrm{c}}$ & $30.59 \pm 0.39^{\mathrm{a}}$ & $30.38 \pm 0.60^{\mathrm{a}}$ & $32.10 \pm 1.09^{b}$ & $30.94 \pm 0.19^{\mathrm{a}}$ \\
\hline PUFA & $22.96 \pm 0.04^{\mathrm{a}}$ & $45.23 \pm 0.45^{\mathrm{b}}$ & $45.37 \pm 0.86^{b}$ & $42.46 \pm 1.98^{\mathrm{b}}$ & $42.16 \pm 2.70^{\mathrm{b}}$ \\
\hline n3 & $1.65 \pm 0.03^{\mathrm{a}}$ & $4.63 \pm 0.07^{\mathrm{c}}$ & $4.50 \pm 0.03^{\mathrm{bc}}$ & $4.38 \pm 0.23^{b}$ & $4.47 \pm 0.03^{\mathrm{bc}}$ \\
\hline$n 6$ & $21.32 \pm 0.01^{\mathrm{a}}$ & $40.60 \pm 0.43^{\mathrm{cd}}$ & $40.87 \pm 0.85^{\mathrm{d}}$ & $38.53 \pm 1.47^{\mathrm{b}}$ & $39.17 \pm 0.13^{b c}$ \\
\hline$n 9$ & $39.23 \pm 0.14^{c}$ & $29.25 \pm 0.37^{\mathrm{a}}$ & $29.33 \pm 0.44^{\mathrm{a}}$ & $30.56 \pm 0.99^{b}$ & $29.56 \pm 0.11^{\mathrm{a}}$ \\
\hline PUFA/SFA & $0.66 \pm 0.002^{\mathrm{a}}$ & $1.88 \pm 0.05^{\mathrm{c}}$ & $1.88 \pm 0.04^{\mathrm{bc}}$ & $1.66 \pm 0.08^{\mathrm{b}}$ & $1.68 \pm 0.08^{\mathrm{b}}$ \\
\hline$n 3 / n 6$ & $12.94 \pm 0.22^{\mathrm{b}}$ & $8.77 \pm 0.14^{\mathrm{a}}$ & $9.19 \pm 0.06^{\mathrm{a}}$ & $8.81 \pm 0.34^{\mathrm{a}}$ & $8.78 \pm 0.06^{\mathrm{a}}$ \\
\hline $\mathrm{AI}^{*}$ & $0.41 \pm 0.003^{\mathrm{c}}$ & $0.23 \pm 0.005^{\mathrm{a}}$ & $0.23 \pm 0.002^{\mathrm{a}}$ & $0.25 \pm 0.004^{\mathrm{b}}$ & $0.25 \pm 0.01^{\mathrm{b}}$ \\
\hline
\end{tabular}

Results are presented as means \pm standard deviation. Means in the same row with different letters are significantly different among formulations ( $<<$ 0.05). -: not detected. C: control patty; EP: enriched patties; EP 0.5\%: enriched patty with 0.5\% of DSS; EP 1\%: enriched patty with 1\% of DSS; EP $2 \%$ : enriched patty with $2 \%$ of DSS; EP $0.01 \%$ BHA: enriched patty with $0.01 \%$ of BHA. SFA: Saturated Fatty Acids, MUFA: Monounsaturated Fatty Acids, PUFA: Polyunsaturated Fatty Acids. *Atherogenic Index calculated as follows: $(\mathrm{C} 12: 0+4 \times \mathrm{C} 14: 0+\mathrm{C} 16: 0) /(\Sigma \mathrm{MUFA}+\Sigma \mathrm{PUFA})$.

burger patties) were healthier due to the higher contents of essential fatty acids and due to the reduction of the atherogenic potential of these meat products [39] [40].

\subsection{Color Changes and Oxidative Stability of Enriched Beef Patties}

The color of meat and meat products after slaughter and manufacturing is altered by increased metmyoglobin [41] and by the addition of ingredients or non-meat substances [42] [43].

Formulation and frozen storage affected color parameters $(p<0.05)$ in some samples as can be observed in Table 4.

Addition of soybean oil affected color parameters compared to the control $(\mathrm{p}<0.05)$ at the beginning of storage. The addition of DSS generally had little effect on color compared to EP 0.01\% BHA (p < 0.05), this effect could be attributed to the decrease of meat content in the formulation; however significant changes were observed at the end of storage ( $p>0.05$ ). The $a^{*}$ value (redness) is the most important color parameter in evaluating meat oxidation, a decrease in redness makes to the meat product unacceptable to consumers [44]. In all samples $a^{*}$ value decreased with frozen storage but the redness of the control samples descended rapidly and at the end of storage was significantly lower $(p<0.05)$ than that of the antioxidant-containing meat products. Dry soybean sprouts incorporated in the patties are potentially useful in prolonging the shelf life of the meat products by preserving of the red color. The results found for color changes are in concordance with the informed by another's researchers [28] [45] [46] in different raw products added with natural ingredients as antioxidants.

Unsaturated fatty acid double bonds occur naturally as methylene interrupted systems. When meat begins to oxidize, the double bonds of these fatty acids shift to create conjugated systems (CD), which can then be measured spectrophotometrically [47]. PV measures the amount of hydroperoxides formed as primary oxidation products at the initial stage of oxidation [47]. These peroxides, however, are very reactive and may actually decrease during the storage of lipid-containing foods [48]. Different concentrations of the natural antioxidant had a 
Table 4. Color parameters of raw enriched patties added with different concentrations of DSS.

\begin{tabular}{ccccccc}
\hline \multirow{2}{*}{ Samples } & \multicolumn{4}{c}{ Parameters } \\
\cline { 2 - 7 } & \multicolumn{2}{c}{$\mathrm{L}^{*}$} & \multicolumn{2}{c}{$\mathrm{a}^{*}$} & \multicolumn{2}{c}{$\mathrm{b}^{*}$} \\
\cline { 2 - 7 } & Day 0 & Day 90 & Day 0 & Day 90 & Day 0 & Day 90 \\
\cline { 2 - 7 } C & $49.95 \pm 0.45^{\mathrm{Ba}}$ & $47.90 \pm 0.67^{\mathrm{ABa}}$ & $6.50 \pm 0.83^{\mathrm{Ab}}$ & $5.20 \pm 0.42^{\mathrm{Aa}}$ & $6.75 \pm 0.68^{\mathrm{Aa}}$ & $7.40 \pm 0.90^{\mathrm{Aa}}$ \\
EP 0.01\% BHA & $47.58 \pm 5.62^{\mathrm{ABa}}$ & $46.05 \pm 1.28^{\mathrm{ABa}}$ & $18.58 \pm 3.16^{\mathrm{Cb}}$ & $9.38 \pm 0.29^{\mathrm{Ba}}$ & $11.58 \pm 2.20^{\mathrm{Bb}}$ & $9.55 \pm 0.87^{\mathrm{ABa}}$ \\
EP 0.5\% DSS & $46.30 \pm 4.39^{\mathrm{ABa}}$ & $48.03 \pm 2.17^{\mathrm{ABa}}$ & $16.03 \pm 2.56^{\mathrm{BCb}}$ & $8.085 \pm 0.46^{\mathrm{Ba}}$ & $10.28 \pm 1.26^{\mathrm{Ba}}$ & $8.70 \pm 0.67^{\mathrm{ABa}}$ \\
EP 1\% DSS & $42.68 \pm 0.38^{\mathrm{Aa}}$ & $44.53 \pm 1.28^{\mathrm{Aa}}$ & $15.25 \pm 2.53^{\mathrm{BCb}}$ & $9.78 \pm 0.50^{\mathrm{Ba}}$ & $11.95 \pm 2.52^{\mathrm{Ba}}$ & $10.93 \pm 0.71^{\mathrm{Ba}}$ \\
EP 2\% DSS & $44.13 \pm 2.37^{\mathrm{ABa}}$ & $49.35 \pm 0.85^{\mathrm{Bb}}$ & $14.08 \pm 3.38^{\mathrm{Bb}}$ & $7.33 \pm 0.10^{\mathrm{Ba}}$ & $11.55 \pm 1.57^{\mathrm{Bb}}$ & $7.68 \pm 0.27^{\mathrm{ABa}}$ \\
\hline
\end{tabular}

Results are presented as means \pm standard deviation. ${ }^{\mathrm{A}}$ Means within a column with different letters are significantly different $(\mathrm{p}<0.05)$. ${ }^{\mathrm{a}}$ Means within a row with different letters are significantly different $(\mathrm{p}<0.05)$.

significant effect on the lipid oxidation of samples ( $p<0.05$ ), as can be observed in Figure 1 . The control treatment had significantly higher PV and TBARS values $(\mathrm{p}<0.05)$ compared to samples with antioxidants at the end of storage (Figure 1), except for CD having EP 2\% DSS the highest value. Fresh meat products can be considered well preserved in regards to oxidative changes [49], when they had less than $3 \mathrm{mg} \mathrm{MDA} / \mathrm{kg}$ sample.

In relation to natural antioxidants from DSS, the concentrations used were satisfactory for maintaining the oxidative stability of the products for three months of frozen storage. These results agree with those reported by others investigators [50]-[52], who reported that mustard leaf, wine industry residues extract and carnosic acid respectively, controlled the lipid oxidation of raw meat products.

The mechanism of the protective effect may be due to the fact that the DSS is rich in SOD who acts purging the oxidized systems from superoxide radical anion (specific effect) [53], phenolic compounds that acts as primary antioxidants or free radical terminators [54], vitamin C (ascorbic acid) whose antioxidant mechanisms are based on hydrogen atom and electron donation to lipid radicals, quenching of singlet oxygen and removal of molecular oxygen [55]. Also, the DSS antioxidant activity has been related with tocopherols and flavonoids regeneration.

Figure 2 shows the inhibition or the reducing percent of lipid oxidation. The samples treated with 1\% of dry soybean sprouts present higher reduction of oxidation than others concentrations of the natural antioxidant. The reducing percentage calculated for TBARS reached $70 \%$ in the samples with $1 \%$ DSS, presenting the same value than those treated with synthetic antioxidant (BHA) at the end of storage, thus indicating high protection of this product against lipid oxidation.

\subsection{Microbiological Analysis}

The shelf-life of raw meat is usually limited by microbial spoilage; hence the control of microbial contamination is a major concern for the meat industry. The assay was performed at zero day of storage to samples C, EP $0.01 \%$ BHA and EP 1\% DSS (due to its highest reducing percent of lipid oxidation) and microbial populations were ranged between 4.30 to $4.84 \log \mathrm{cfu} / \mathrm{g}(\mathrm{p}<0.05)$. These results agree with the informed by others investigators [37] [45]. Addition DSS affect the microbial status of beef patties relative to the controls, presumably due to the product formulations, although did not exceed 6 log cfu/g [37].

\section{Conclusion}

Results of the present study indicate that dry soybean sprouts possess a good level of SOD, high total phenolics and flavonoids content, and also of vitamin C. Although reduction power was not good enough, DPPH and ABTS radicals scavenging activity were elevated. When DSS were incorporated to meat samples at different concentrations, not affected nutritional value or lipidic profile of enriched beef patties with soybean oil, and meat color, specifically red, was preserved. The lipid oxidation was inhibited in all cases, and was strongly effective to concentrations of $1 \%$ DSS. The results shown in this research suggest that dry soya sprouts could be used as a natural antioxidant for meat and meat products. Further investigations are necessary to evaluate their sensorial influence and microbiological safety during storage. 


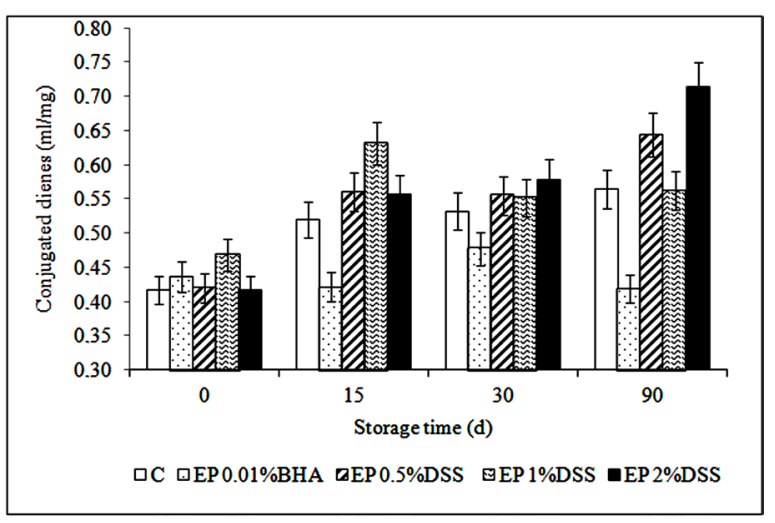

(a)

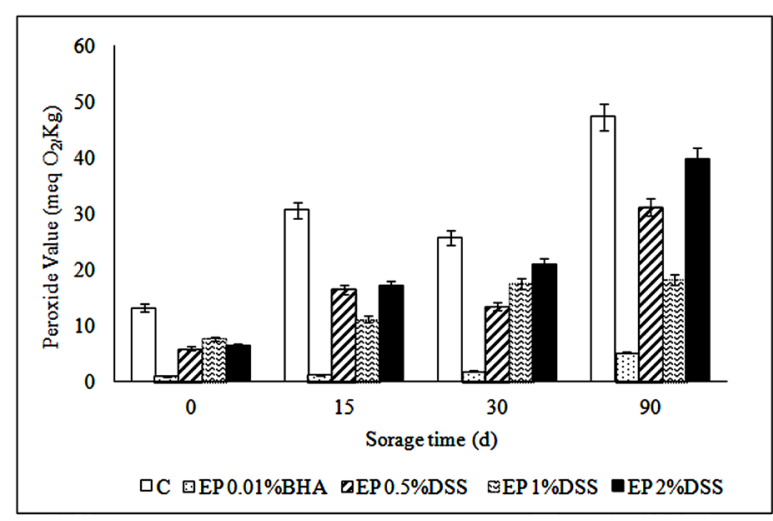

(b)

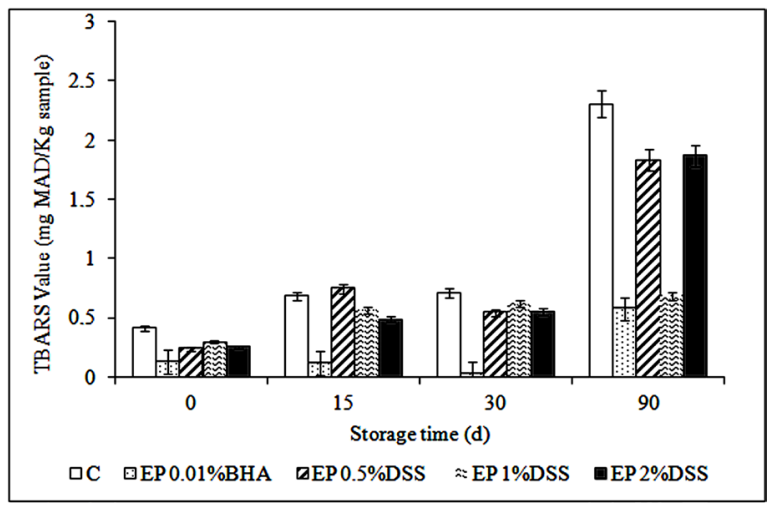

(c)

Figure 1. Effect of dry soybean sprouts ( $0 \% ; 0.5 \% ; 1 \%$ and $2 \%$ ) on (a) Conjugated dienes; (b) Peroxide values; and (c) TBARS in enriched patties with soybean oil. Data represent the means \pm SD $(p<0.05)$.

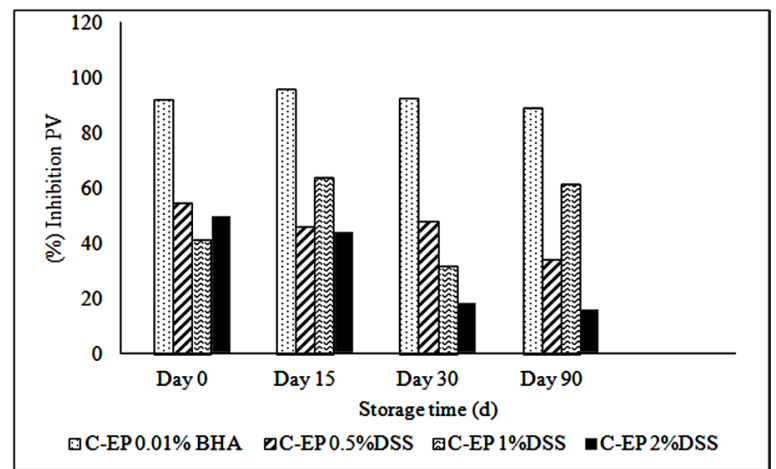

(a)

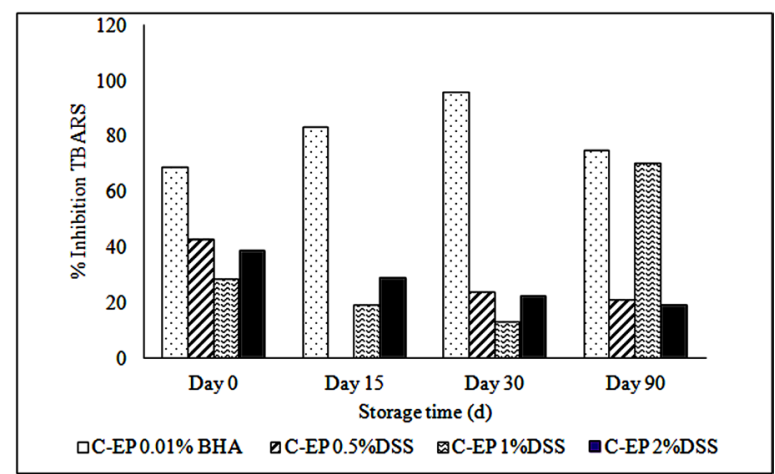

(b)

Figure 2. Inhibition percent of lipid oxidation by different DSS concentration. (a) Inhibition percent on hydroperoxides formation; and (b) Inhibition percent on TBARS formation.

\section{Acknowledgements}

This research was supported by Consejo Nacional de Investigaciones Científicas y Técnicas (CONICET, Argentina), and Universidad Nacional de Chaco Austral. The authors acknowledge the contributions of Cooperativa la Unión, Ltda.

\section{References}

[1] Greene, B.E., Hsin, I.M. and Zisper, M.W. (1971) Retardation of Oxidative Color Changes in Raw Ground Beef. Jour- 
nal of Food Science, 36, 940-942. http://dx.doi.org/10.1111/j.1365-2621.1971.tb15564.x

[2] Haworth, J.E. (2003) Natural Antioxidants Review. Proceedings of the 56th Reciprocal Meats Conference, Columbia, 15-18 June 2003, 95-98.

[3] Gardner, H.W. (1979) Lipid Hydroperoxide Reactivity with Proteins and Aminoacids: A Review. Journal of Agricultural and Food Chemistry, 27, 220-229. http://dx.doi.org/10.1021/jf60222a034

[4] Shahidi, F. and Zhong, Y. (2010) Lipid Oxidation and Improving The Oxidative Stability. Chemical Society Reviews, 39, 4067-4079. http://dx.doi.org/10.1039/b922183m

[5] Paucar-Menacho, L.M., Berhow, M.A., Mandarino, J.M.G., Gonzalez de Mejia, E. and Chang, J.K. (2010) Optimisation of Germination Time and Temperature on the Concentration of Bioactive Compounds in Brazilian Soybean Cultivar BRS 133 Using Response Surface Methodology. Food Chemistry, 119, 636-642. http://dx.doi.org/10.1016/j.foodchem.2009.07.011

[6] Zhu, D., Hettiarachchy, N., Horax, R. and Chen, P. (2005) Isoflavone Contents in Germinated Soybean Seeds. Plant Foods Human Nutrition, 60, 147-151. http://dx.doi.org/10.1007/s11130-005-6931-0

[7] Viña, S.Z. and Chaves, A. (2003) IV Gama. Tecnologías aptas para la conservación de hortalizas. Magazine Information on Agricultural Research and Development. National Institute of Agricultural Technology, XXI, 37-41.

[8] Muguerza, E., Ansorena, D. and Astiasarán, I. (2003) Improvement of Nutricional Properties of Chorizo de Pamplona by Replacement of Pork Backfat with Soy Oil. Meat Science, 65, 1361-1367. http://dx.doi.org/10.1016/S0309-1740(03)00058-5

[9] Choi, Y.S., Choi, J.H., Han, D.J., Kim, H.Y., Lee, M.A., Jeong, J.Y., Chung, H.J. and Kim, C.J. (2010) Effects of Replacing Pork Back Fat with Vegetable Oils and Rice Bran Fiber on the Quality of Reduced-Fat Frankfurters. Meat Science, 84, 557-563. http://dx.doi.org/10.1016/j.meatsci.2009.10.012

[10] Jung, E. and Joo, N. (2013)Roselle (Hibiscus sabdariffa L.) and Soybean Oil Effects on Quality Characteristics of Pork Patties Studied by Response Surface Methodology. Meat Science, 94, 391-401. http://dx.doi.org/10.1016/j.meatsci.2013.02.008

[11] Bamforth, C.W. (1983) Superoxide Dismutase in Barley. Journal of the Institute of Brewing, 89, 420-423. http://dx.doi.org/10.1002/j.2050-0416.1983.tb04218.x

[12] Kalogeropoulos, N., Yannakopoulou, K., Gioxari, A., Chiou, A. and Makris, D. (2010) Polyphenol Characterization and Encapsulation in b-Cyclodextrin of a Flavonoid-Rich Hypericum perforatum (St John's Wort) Extract. Food Science and Technology, 43, 882-889. http://dx.doi.org/10.1016/j.lwt.2010.01.016

[13] Kim, D., Jeong, S. and Lee, C. (2003) Antioxidant Capacity of Phenolic Phytochemicals from Various Cultivars of Plums. Food Chemistry, 81, 321-326. http://dx.doi.org/10.1016/S0308-8146(02)00423-5

[14] Oyaizu, M. (1986) Studies on Products of Browning Reactions: Antioxidative Activities of Product of Browning Reaction Prepared from Glucosamine. Japan Journal of Nutrition, 44, 307-315. http://dx.doi.org/10.5264/eiyogakuzashi.44.307

[15] Re, R., Pellegrini, N., Proteggente, A., Pannala, A., Yang, M. and Rice-Evans, C. (1999) Antioxidant Activity Applying an Improved ABTS Radical Cation Decolorization Assay. Free Radical Biology and Medicine, 26, 1231-1237. http://dx.doi.org/10.1016/S0891-5849(98)00315-3

[16] Siddhuraju, P., Mohan, P. and Becker, K. (2002) Studies on the Antioxidant Activity of Indian Laburnum (Cassia fistula L): A Preliminary Assessment of Crude Extracts from Stem Bark, Leaves, Flowers and Fruit Pulp. Food Chemistry, 79, 61-67. http://dx.doi.org/10.1016/S0308-8146(02)00179-6

[17] Zhou, K., Yin, J.J. and Yu, L. (2005) Phenolic Acid, Tocopherol and Carotenoid Compositions, and Antioxidant Functions of Hard Red Winter Wheat Bran. Journal of Agricultural and Food Chemistry, 53, 3916-3922. http://dx.doi.org/10.1021/jf050117c

[18] AOAC (1990) Association of Official Analytical Chemist. 15th Edition, Washington DC.

[19] Clegg, K.M. (195) The Application of the Anthrone Reagent to the Estimation of Starch in Cereals. Journal of the Science of Food and Agriculture, 7, 40-44. http://dx.doi.org/10.1002/jsfa.2740070108

[20] Bligh, E. and Dyer, W. (1959) A Rapid Method of Total Lipid Extraction and Purification. Canadian Journal of Biochemistry and Physiology, 37, 911-917. http://dx.doi.org/10.1139/059-099

[21] Aubourg, S. (1998) Lipid Changes during Long-Term Storage of Canned Tuna (Thunnus alalunga). Zeitschrift für Lebensmittel-Untersuchung und -Forschung, 206, 33-37. http://dx.doi.org/10.1007/s002170050209

[22] Shanta, N.C. and Decker, E.A. (1994) Rapid, Sensitive, Iron-Based Spectrophotometric Methods for Determination of Peroxide Values of Food Lipids. Journal of AOAC International, 77, 421-424.

[23] Ahn, D.U. and Kim, S.M. (1998) Prooxidant Effects of Ferrous Iron, Hemoglobin, and Ferritin in Oil Emulsion and Cooked Meat Homogenates Are Different from Those in Raw Meat Homogenates. Poultry Science, 77, 348-355. 
[24] Kumar, U., Mishra, M. and Prakash, V. (2012) Assessment of Antioxidant Enzymes and Free Radical Scavenging Activity of Selected Medicinal Plants. Free Radicals and Antioxidants, 2, 58-63. http://dx.doi.org/10.5530/ax.2012.3.8

[25] Roginsky, V. and Lissi, E. (2005) Review of Methods to Determine Chain-Breaking Antioxidant Activity in Food. Food Chemistry, 92, 235-254. http://dx.doi.org/10.1016/j.foodchem.2004.08.004

[26] Liu, J., Wang, J., Yin, M., Zhu, H., Lu, J. and Cui, Z. (2011) Purification and Characterization of Superoxide Dismutase from Garlic. Food and Bioproducts Processing, 89, 294-299. http://dx.doi.org/10.1016/j.fbp.2010.07.003

[27] Romero, A.M., Doval, M.M., Romero, M.C., Sturla, M.A. and Judis, M.A. (2008) Antioxidant Properties of Soya Sprout Hydrophilic Extracts. Application to Cooked Chicken Patties. Electronic Journal of Environmental Agricultural and Food Chemistry, 7, 3196-3206.

[28] Schwarz, K., Bertelsen, G., Nissen, L., Gardner, P., Heinonem, M., Hopia, A., Huynh-ba, P., Lambelet, T., Mcphail, D., Skibsted, L. and Tijburg, L. (2001) Investigation of Plants Extracts for the Protection of Processed Foods against Lipid Oxidation. Comparison of Antioxidant Assays Based on Radical Scavenging, Lipid Oxidation and Analysis of the Principal Antioxidant Compounds. European Food Research and Technology, 212, 319-328. http://dx.doi.org/10.1007/s002170000256

[29] Kim, S.J., Min, S.C., Shin, H.J., Lee, Y.J., Cho, A.R., Kim, S.Y. and Han, J. (2013) Evaluation of the Antioxidant Activities and Nutritional Properties of Ten Edible Plant Extracts and Their Application to Fresh Ground Beef. Meat Science, 93, 715-722. http://dx.doi.org/10.1016/j.meatsci.2012.11.029

[30] Bau, H.M., Villaume, C., Nicolas, J.P. and Méjean, L. (1997) Effect of Germination on Chemical Composition, Biochemical Constituents and Antinutritional Factors of Soya Bean (Glycine max) Seeds. Journal of Science Food and Agricultural, 73, 1-9. http://dx.doi.org/10.1002/(SICI)1097-0010(199701)73:1<1::AID-JSFA694>3.0.CO;2-B

[31] Amarowicz, R., Pegg, R.B., Rahimi-Moghaddam, P., Barl, B. and Weil, J.A. (2004) Free-Radical Scavenging Capacity and Antioxidant Activity of Selected Plant Species from the Canadian Prairies. Food Chemistry, 84, 551-62. http://dx.doi.org/10.1016/S0308-8146(03)00278-4

[32] Nanjo, F., Gotto, K., Seto, R., Suzuki, M., Sakai, M. and Hara, Y. (1996) Scavenging Effects of Tea Catechins and Their Derivatives on 1,1-Diphenyl-2-picrylhydrazyl Radical. Free Radical Biology \& Medicine, 21, 895-902. http://dx.doi.org/10.1016/0891-5849(96)00237-7

[33] Ndife, J., Abdulraheem, L.O. and Zakari, U.M. (2011) Evaluation of the Nutritional and Sensory Quality of Functional Breads Produced from Whole Wheat and Soya Bean Flour Blends. African Journal of Food Science, 5, 466-472. http://www.academicjournals.org/ajfs

[34] Eze, V.C., Okoye, J.L., Agwung, F.D. and Nnabueke, C. (2008) Chemical and Microbiological Evaluation of Soybean Flours Bought from Local Markets in Onitsha, Anambra State, Nigeria. Continental Journal of Applied Sciences, 3 , 39-45.

[35] Serdaroğlu, M. (2006) The Characteristics of Beef Patties Containing Different Levels of Fat and Oat Flour. International Journal of Food Science and Technology, 41, 147-153. http://dx.doi.org/10.1111/j.1365-2621.2005.01041.x

[36] Alakali, J.S., Irtwange, S.V. and Mzer, M.T. (2010) Quality Evaluation of Beef Patties Formulated with Bambara Groundnut (Vigna subterranean L.) Seed Flour. Meat Science, 85, 215-223. http://dx.doi.org/10.1016/j.meatsci.2009.12.027

[37] López-López, I., Cofrades, S., Yakan, A., Solas, M.T. and Jiménez-Colmenero, F. (2010) Frozen Storage Characteristics of Low-Salt and Low-Fat Beef Patties as Affected by Wakame Addition and Replacing Pork Backfat with Olive Oil-in-Water Emulsion. Food Research International, 43, 1244-1254. http://dx.doi.org/10.1016/j.foodres.2010.03.005

[38] Wood, J.D., Enser, M., Fisher, A.V., Nute, G.R., Sheard, P.R., Richardson, R.I., Hughes, S.I. and Whittington, F.M. (2008) Fat Deposition, Fatty Acid Composition and Meat Quality: A Review. Meat Science, 78, 343-358. http://dx.doi.org/10.1016/j.meatsci.2007.07.019

[39] López-López, I., Cofrades, S., Cañeque, V., Díaz, M.T., López, O. and Jiménez-Colmenero, F. (2011) Effect of Cooking on the Chemical Composition of Low-Salt, Low-Fat Wakame/Olive Oil Added Beef Patties with Special Reference to Fatty Acid Content. Meat Science, 89, 27-34. http://dx.doi.org/10.1016/j.meatsci.2011.03.016

[40] Salcedo-Sandoval, L., Cofrades, S., Ruiz-Capillas Pérez, C., Solas, M.T. and Jiménez-Colmenero, F. (2013) Healthier Oils Stabilized in Konjac Matrix as Fat Replacers in n - 3 PUFA Enriched Frankfurters. Meat Science, 93, 757-766. http://dx.doi.org/10.1016/j.meatsci.2012.11.038

[41] Faustman, C. and Cassens, R.G. (1990) The Biochemical Basis for Discoloration in Fresh Meat: A Review. Journal of Muscle Foods, 1, 217-243. http://dx.doi.org/10.1111/j.1745-4573.1990.tb00366.x

[42] Hunt, M.C., Sorheim, O. and Slinde, E. (1995) Effects of Myoglobin Form on Internal Cooked Color Development in Ground Beef. Proceedings of the 41st International Congress of Meat Science and Technology, San Antonio, 20-25 August 1995, 394-395.

[43] Pietrasik, Z. and Janz, J.A.M. (2009) Influence of Freezing and Thawing on the Hydration Characteristics, Quality, and 
Consumer Acceptance of Whole Muscle Beef Injected with Solutions of Salt and Phosphate. Meat Science, 81, 523532. http://dx.doi.org/10.1016/j.meatsci.2008.10.006

[44] Renerre, M. (2000) Review: Biochemical Basis of Freshmeat Color. Proceedings of the 45th International Congress of Meat Science and Technology, 1-6 August 1999, Yokohama, 344-352.

[45] Moroney, N.C., O’Grady, M.N., O’Doherty, J.V. and Kerry, J.P. (2013) Effect of a Brown Seaweed (Laminaria digitata) Extract Containing Laminarin and Fucoidan on the Quality and Shelf-Life of Fresh and Cooked Minced Pork Patties. Meat Science, 94, 304-311. http://dx.doi.org/10.1016/j.meatsci.2013.02.010

[46] Kim, H.W., Choia, Y.S., Choia, J.H., Kim, H.Y., Hwang, K.E., Song, D.H., Lee, S.Y., Lee, M.A. and Kim, C.J. (2013) Antioxidant Effects of Soy Sauce on Color Stability and Lipid Oxidation of Raw Beef Patties during Cold Storage. Meat Science, 95, 641-646. http://dx.doi.org/10.1016/j.meatsci.2013.06.006

[47] Teets, A.S. and Were, L.M. (2008) Inhibition of Lipid Oxidation in Refrigerated and Frozen Salted Raw Minced Chicken Breasts with Electron Beam Irradiated almond Skin Powder. Meat Science, 80, 1326-1332. http://dx.doi.org/10.1016/j.meatsci.2008.06.010

[48] Juntachote, T., Berghofer, S., Siebenhandl, S. and Bauer, F. (2007) The Effect of Dried Galangal Powder and Its Ethanolic Extracts on Oxidative Stability in Cooked Ground Pork. LWT-Food Science and Technology, 40, 324-330.

[49] Chouliara, E., Badeka, A., Savvaidis, I. and Kontominas, M.G. (2008) Combined Effect of Irradiation and Modified Atmosphere Packaging on Shelf-Life Extension of Chicken Breast Meat: Microbiological, Chemical and Sensory Changes. European Food Research and Technology, 226, 877-888. http://dx.doi.org/10.1007/s00217-007-0610-3

[50] Lee, M.A., Choi, J.H., Choi, Y.S., Han, D.J., Kim, H.Y., Shim, S.Y., Chung, H.K. and Kim, C.J. (2010) The Antioxidative Properties of Mustard Leaf (Brassica juncea) Kimchi Extracts on Refrigerated Raw Ground Pork Meat against Lipid Oxidation. Meat Science, 84, 498-504. http://dx.doi.org/10.1016/j.meatsci.2009.10.004

[51] Selani, M.M., Contreras-Castillo, C.J., Shirahigue, L.D., Gallo, C.R., Plata-Oviedo, M. and Montes-Villanueva, N.D. (2011) Wine Industry Residues Extracts as Natural Antioxidants in Raw and Cooked Chicken Meat during Frozen Storage. Meat Science, 88, 397-403. http://dx.doi.org/10.1016/j.meatsci.2011.01.017

[52] Naveena, B.M., Vaithiyanathan, S., Muthukumar, M., Sen, A.R., Praveen Kumar, Y., Kiran, M., Shaju, V.A. and Ramesh Chandran, K. (2013) Relationship between the Solubility, Dosage and Antioxidant Capacity of Carnosic Acid in Raw and Cooked Ground Buffalo Meat Patties and Chicken Patties. Meat Science, 95, 195-202. http://dx.doi.org/10.1016/j.meatsci.2013.04.043

[53] Roginsky, V. and Barsukova, T. (2001) Superoxide Dismutase Inhibits Lipid Peroxidation in Micelles. Chemistry and Physics of Lipids, 111, 87-91. http://dx.doi.org/10.1016/S0009-3084(01)00148-7

[54] Juntachote, T., Berghofer, E., Siebenhandl, S. and Bauer, F. (2006) The Antioxidative Properties of Holy Basil and Galangal in Cooked Ground Pork. Meat Science, 72, 446-456. http://dx.doi.org/10.1016/j.meatsci.2005.08.009

[55] Lee, J., Koo, N. and Min, D.B. (2004) Reactive Oxygen Species, Aging, and Antioxidative Nutraceuticals. Comprehensive Reviews in Food Science and Food Safety, 3, 21-33. http://dx.doi.org/10.1111/j.1541-4337.2004.tb00058.x 